\title{
Cross-Reactive Immune Responses toward the Common Cold Human Coronaviruses and Severe Acute Respiratory Syndrome Coronavirus 2 (SARS-CoV-2): Mini-Review and a Murine Study
}

\author{
Robert E. Sealy ${ }^{1}$ and Julia L. Hurwitz ${ }^{1,2, *}$ \\ 1 Department of Infectious Diseases, St. Jude Children's Research Hospital, Memphis, TN 38105, USA; \\ bob.sealy@stjude.org \\ 2 Department of Microbiology, Immunology and Biochemistry, University of Tennessee Health Science Center, \\ Memphis, TN 38163, USA \\ * Correspondence: julia.hurwitz@stjude.org; Tel.: +1-901-595-2464
}

check for

updates

Citation: Sealy, R.E.; Hurwitz, J.L. Cross-Reactive Immune Responses toward the Common Cold Human Coronaviruses and Severe Acute Respiratory Syndrome Coronavirus 2 (SARS-CoV-2): Mini-Review and a Murine Study. Microorganisms 2021, 9 , 1643. https://doi.org/10.3390/ microorganisms 9081643

Academic Editor: Stefano Aquaro

Received: 8 June 2021

Accepted: 26 July 2021

Published: 31 July 2021

Publisher's Note: MDPI stays neutral with regard to jurisdictional claims in published maps and institutional affiliations.

Copyright: (c) 2021 by the authors. Licensee MDPI, Basel, Switzerland. This article is an open access article distributed under the terms and conditions of the Creative Commons Attribution (CC BY) license (https:// creativecommons.org/licenses/by/ $4.0 /)$.

\begin{abstract}
While severe acute respiratory syndrome coronavirus 2 (SARS-CoV-2) causes serious morbidity and mortality in humans (coronavirus disease 2019, COVID-19), there is an enormous range of disease outcomes following virus exposures. Some individuals are asymptomatic while others succumb to virus infection within days. Presently, the factors responsible for disease severity are not fully understood. One factor that may influence virus control is pre-existing immunity conferred by an individual's past exposures to common cold human coronaviruses (HCoVs). Here, we describe previous literature and a new, murine study designed to examine cross-reactive immune responses between SARS-CoV-2 and common cold HCoVs (represented by prototypes OC43, HKU1, 229E, and NL63). Experimental results have been mixed. In SARS-CoV-2-unexposed humans, cross-reactive serum antibodies were identified toward nucleocapsid $(\mathrm{N})$ and the spike subunit $\mathrm{S} 2$. S2-specific antibodies were in some cases associated with neutralization. SARS-CoV-2-unexposed humans rarely exhibited antibody responses to the SARS-CoV-2 spike subunit S1, and when naïve mice were immunized with adjuvanted S1 from either SARS-CoV-2 or common cold HCoVs, S1-specific antibodies were poorly cross-reactive. When humans were naturally infected with SARS-CoV-2, cross-reactive antibodies that recognized common cold $\mathrm{HCoV}$ antigens increased in magnitude. Cross-reactive T cells, like antibodies, were present in humans prior to SARS-CoV-2 exposures and increased following SARS-CoV-2 infections. Some studies suggested that human infections with common cold HCoVs afforded protection against disease caused by subsequent exposures to SARSCoV-2. Small animal models are now available for the testing of controlled SARS-CoV-2 infections. Additionally, in the United Kingdom, a program of SARS-CoV-2 human challenge experiments has received regulatory approval. Future, controlled experimental challenge studies may better define how pre-existing, cross-reactive immune responses influence SARS-CoV-2 infection outcomes.
\end{abstract}

Keywords: SARS-CoV-2; common cold human coronaviruses; cross-reactive antibodies

\section{Severe Acute Respiratory Syndrome Coronavirus 2}

Severe acute respiratory syndrome coronavirus 2 (SARS-CoV-2) is an RNA virus that was first identified in Wuhan China in December 2019 [1,2]. It has since been the cause of an unprecedented global pandemic. As of 12 July 2021, there were more than 33 million cases of SARS-CoV-2 in the United States and more than 600,000 reported deaths. Globally, there were more than 186 million cases and more than four million deaths [3]. The symptoms of disease (coronavirus disease 2019, COVID-19) usually occur 2-14 days after a virus exposure and can include fever, dry cough, shortness of breath, difficulty breathing, fatigue, body aches, headache, loss of smell/taste, sore throat, nasal congestion, rhinorrhea, loss of appetite, nausea, vomiting and diarrhea. While SARS-CoV-2 is generally recognized as a respiratory disease, viral RNA has been detected in more than $50 \%$ stool 
samples within some patient populations [4]. Individuals over 65 years of age and those with underlying medical conditions including cancer, obesity, chronic kidney disease, heart/lung disease, and diabetes are particularly vulnerable to serious disease caused by SARS-CoV-2. Children are often asymptomatic, but can suffer a rare, serious disease, termed multisystem inflammatory syndrome in children (MIS-C) [5].

Coronaviruses are spherical, enveloped viruses with a positive single strand RNA genome. SARS-CoV-2 is a betacoronavirus, one of four different genera (alpha, beta, gamma, delta) of coronaviruses [6]. The first sequenced SARS-CoV-2 genome, approximately 30 kilobases $(\mathrm{kb})$ in length, is available in the NCBI GenBank database (Accession\# NC_045512) [1,2]. Four major structural proteins of the virus are nucleocapsid (N), spike (S), envelope (E), and membrane (M) [6,7]. The $\mathrm{N}$ protein forms a complex with viral RNA to form a helical capsid. S, E, and $\mathrm{M}$ are all membrane proteins. The S membrane protein supports virus interaction with the target mammalian cell. Two $S$ protein subunits are $\mathrm{S} 1$ and $\mathrm{S} 2$. The $\mathrm{S} 1$ subunit includes the receptor binding domain (RBD) that links virus to its host receptor, the angiotensin-converting enzyme 2 (ACE2) on mammalian cells, and the S2 subunit supports fusion of virus with the mammalian cell membrane [6]. The $\mathrm{E}$ protein forms a cation-selective channel and mediates virus budding and release [8]. The $\mathrm{M}$ protein contributes to virus assembly and budding. The expression of $\mathrm{M}$ with $\mathrm{E}$ is sufficient to form virus-like particles in the absence of other viral proteins and RNA [9].

Vaccines have been rapidly developed and released for the prevention of SARS-CoV2 [10-14], but as of July 2021, vaccines were received by only a fraction of the world population. The pandemic of SARS-CoV-2 continues today as scientists and community leaders strategize to administer vaccines worldwide and quell the spread and evolution of virus. During the pandemic, SARS-CoV-2 variants of concern (VOC) have gained dominance in certain human populations. Some VOCs include B.1.1.7, B.1.351, P.1, and B.1.617.2 (also known respectively as alpha, beta, gamma and delta variants). VOCs were first detected in the United Kingdom, South Africa, Brazil, and India, but quickly spread beyond the countries of origin. Debates are ongoing as to whether current vaccines are adequate to cover VOCs or whether vaccines must be altered to combat new viral mutations [15].

\section{Common Cold Human Coronaviruses (HCoV)}

The common cold HCoVs are usually associated with mild disease in the human population [16,17]. Serological studies suggest that most individuals have been exposed to the common cold HCoVs [18]. Typically, disease is restricted to the upper respiratory tract and virus is rapidly cleared. Symptoms may include rhinitis, pharyngitis, sneezing, hoarseness, and cough [19]. However, common cold HCoVs can also cause serious disease consequences. Advanced age, pre-existing heart and/or lung conditions, and immunodeficiencies can render patients particularly vulnerable to severe disease outcomes [20].

The common cold $\mathrm{HCoVs}$ are represented by four viral prototypes, originally categorized serologically. There are contrasting reports in the literature concerning the first isolation of these four strains [6,21,22]. The alphacoronaviruses are NL63 and 229E. The first isolation of NL63 was reported to have occurred in the Netherlands with a sample derived from a child with bronchiolitis [23-25]. The first isolation of 229E was reported to have been by Hamre and Procknow who passaged specimens from students with respiratory symptoms at the University of Chicago, USA [22]. Almeida and Tyrrell in the United Kingdom later received 229E from Hamre for further analyses and comparison to other virus isolates (e.g., B814) [26-31]. OC43 and HKU1, like SARS-CoV-2, are betacoronaviruses. The first isolation of OC43 was reported to have been by McIntosh et al. at the National Institutes of Health, USA. These investigators used specimens from patients with common cold symptoms and employed an embryonic trachea organ culture method that was previously developed by Tyrell and colleagues to isolate virus [26,32-35]. HKU1 was reported to have derived from a hospitalized adult man with chronic pulmonary disease in Hong Kong [25,36-38]. 229E and OC43 were first described in the 1960s, while NL63 and 
HKU1 were first described in 2004-2005 [39]. In early years, electron microscopy studies were used to characterize viral morphology, revealing a crown-like structure or 'corona' on each of the isolates [21]. SARS-CoV-2 is better related to OC43 and HKU1 than NL63 and 229E by sequence (sequence alignments and phylogenetic trees of coronaviruses are described by Gussow et al.) [40]. SARS-CoV-2 and NL63 are related in that they share ACE2 binding $[6,22,25,32,34,36,38,39,41-45]$.

\section{Human Responses toward SARS-CoV-2 in SARS-CoV-2 Unexposed Individuals}

Given that many individuals have been exposed to common cold $\mathrm{HCoV}$ and have generated $\mathrm{HCoV}$-specific B cell and T cell responses [46,47], a pertinent question is whether common cold HCoV-specific antibodies and T cells cross-react with SARS-CoV-2. Research has yielded variable results $[17,47-55]$.

In order to address the question, one strategy was to examine sera from SARS-CoV2-unexposed individuals, usually acquired before the SARS-CoV-2 pandemic began. Researchers asked if these 'pre-pandemic' samples contained SARS-CoV-2-specific antibodies. The results of a few reports are shown in Table 1. As shown, there were variable levels of SARS-CoV-2-specific antibodies found in SARS-CoV-2-unexposed individuals. Common antibody targets were $\mathrm{N}$ and S2. In some cases, S2-specific antibodies were associated with neutralization.

In a separate report by Shiakolas et al. [51], human monoclonal antibodies with SARS-CoV-2 $\mathrm{S}$ binding were synthesized and studied to test for cross-reactive potentials. Antibody variable region sequences were from a blood donor who had been exposed to SARS-CoV-1 more than ten years prior to sample collection (potential exposures to other coronaviruses were not reported). The procedure began by purification of donor $\mathrm{B}$ cells based on their binding to at least one coronavirus $\mathrm{S}$ antigen within an antigen pool. This was followed by the sequencing of corresponding immunoglobulin genes using LIBRA-Seq (a high-throughput sequencing program designed to link B cell receptors with antigen specificities), and the selection of variable gene sequences for expression in custom plasmids. Six monoclonals were generated that bound SARS-CoV-1 S and SARS-CoV-2 S. Two of these monoclonals also bound HKU1 S and OC43 S, albeit weakly. One of the two antibodies with HKU1 S and OC43 $\mathrm{S}$ binding also bound the $\mathrm{N}$ terminal domain of SARS-CoV-2 S1 while the second monoclonal bound the SARS-CoV-2 RBD. The RBDspecific monoclonal supported Fc effector functions including antibody-dependent cellular phagocytosis in vitro, but no significant neutralization. In an in vivo experiment with a mouse modified SARS-CoV-2 challenge, the RBD-specific antibody did not significantly reduce viral loads or improve animal survival, but reduced pulmonary hemorrhage (scored by lung color at the time of mouse sacrifice). 
Table 1. Antibody activities in humans with no known SARS-CoV-2 exposures.

\begin{tabular}{|c|c|c|c|}
\hline Authors & Manuscript Title & Results & Paper \\
\hline Khan et al. & $\begin{array}{l}\text { Cross-reactivity between common human } \\
\text { coronaviruses and SARS-Cov-2 using coronavirus } \\
\text { antigen microarray }\end{array}$ & $\begin{array}{l}\text { Khan et al. used pre-pandemic sera and antigen microarrays to study antibody responses. } \\
\text { They observed IgG reactivity toward each of the common cold HCoVs in four of five tested } \\
\text { serum samples, but only weak IgG reactivity toward SARS-CoV-2 in all five samples. Weak } \\
\text { signals were directed toward SARS-CoV-2 N and S2 antigens. }\end{array}$ & {$[47]$} \\
\hline Guo et al. & $\begin{array}{l}\text { Profiling early humoral response to diagnose } \\
\text { novel coronavirus disease (COVID-19) }\end{array}$ & $\begin{array}{l}\text { Guo et al. did not observe SARS-CoV-2 N-specific antibodies within pre-pandemic samples } \\
\text { that exhibited positive antibodies toward N proteins of NL63, 229E, OC43, and HKU1. }\end{array}$ & [56] \\
\hline Mveang Nzoghet al. & $\begin{array}{l}\text { Evidence and implications of pre-existing } \\
\text { humoral cross-reactive immunity to SARS-CoV-2. }\end{array}$ & $\begin{array}{l}\text { Mveang Nzoghe et al. tested samples from healthy volunteers taken in 2014. Of } 135 \\
\text { samples, } 32(23.7 \%) \text { tested positive for antibodies against SARS-CoV-2 N. }\end{array}$ & {$[57]$} \\
\hline To et al. & $\begin{array}{l}\text { Seroprevalence of SARS-CoV-2 in Hong Kong and } \\
\text { in residents evacuated from Hubei province, } \\
\text { China: a multicohort study. }\end{array}$ & $\begin{array}{c}\text { To et al. found that in a Hong Kong population presumed to be SARS-CoV-2-unexposed, } \\
53 \text { of } 1938 \text { samples ( } 2.73 \% \text { ) were positive for antibody binding in a SARS-CoV-2 } \\
\text { enzyme-linked immunosorbent assay (ELISA). }\end{array}$ & {$[17,58,59]$} \\
\hline Shrock et al. & $\begin{array}{l}\text { Viral epitope profiling of COVID-19 patients } \\
\text { reveals cross-reactivity and correlates of severity. }\end{array}$ & $\begin{array}{l}\text { Using VirScan technology, Shrock et al. observed antibodies to SARS-CoV-2 ORF-1, but } \\
\text { relatively weak or no activity toward SARS-CoV-2 S or N among } 190 \\
\text { pre-pandemic samples. }\end{array}$ & {$[60]$} \\
\hline Anderson et al. & $\begin{array}{l}\text { Seasonal human coronavirus antibodies are } \\
\text { boosted upon SARS-CoV-2 infection but not } \\
\text { associated with protection. }\end{array}$ & $\begin{array}{l}\text { Anderson et al. reported that in pre-pandemic samples taken in } 2017 \text {, there was antibody } \\
\text { binding to SARS-CoV- } 2 \text { full-length S in } 5.4 \% \text { samples and antibody binding to SARS-CoV-2 } \\
\text { RBD of the S protein in } 2 \% \text { of the samples. SARS-CoV-2 N-specific antibodies were } \\
\text { detected in } 18.6 \% \text { of the samples. In this case, antibodies were non-neutralizing. }\end{array}$ & [46] \\
\hline Tso et al. & $\begin{array}{c}\text { High prevalence of pre-existing serological } \\
\text { cross-reactivity against severe acute respiratory } \\
\text { syndrome coronavirus-2 (SARS-CoV-2) in } \\
\text { sub-Saharan Africa. }\end{array}$ & $\begin{array}{l}\text { Tso et al. identified higher frequencies of SARS-CoV-2-specific antibodies in their study of } \\
\text { pre-pandemic samples from individuals in African countries compared to individuals in } \\
\text { the USA. Specifically, the prevalence of serological activity against SARS-COV-2 in assays } \\
\text { was } 19 \% \text { among samples from Tanzania and } 14.1 \% \text { among samples from Zambia, but only } \\
2.4 \% \text { among samples from the USA. Among the samples from Africa, responses toward N } \\
\text { were higher than those toward S. }\end{array}$ & [61] \\
\hline Nguyen-Contant et al. & $\begin{array}{l}\text { S protein-reactive IgG and memory B cell } \\
\text { production after human SARS-Cov- } 2 \text { infection } \\
\text { includes broad reactivity to the S2 subunit. }\end{array}$ & $\begin{array}{l}\text { Nguyen-Contant et al. examined } 21 \text { pre-pandemic samples collected from } 2011 \text { to } 2014 \text { at } \\
\text { the University of Rochester (Rochester, New York, USA). Antibody responses toward } \\
\text { SARS-CoV-2 were generally weak. Nonetheless, authors detected serum IgG toward a } \\
\text { stabilized ectodomain of SARS-CoV-2 S. The responses were also identified toward } \\
\text { SARS-CoV-2 N. Responses toward the SARS-CoV-2 RBD were not identified, but } 86 \% \text { of } \\
\text { samples bound SARS-CoV-2 S2. The authors contemplated that responses toward S2 might } \\
\text { provide neutralizing activity and a degree of protection against SARS-CoV-2 in humans. }\end{array}$ & [62] \\
\hline
\end{tabular}


Table 1. Cont.

Authors Manuscript Title

\section{Results}

Paper

$\mathrm{Ng}$ et al. frequently observed SARS-CoV-2 S-specific antibodies in SARS-CoV-2 unexposed

$\mathrm{Ng}$ et al. $\quad$ Preexisting and de novo humoral immunity to $\quad \begin{aligned} & \text { individuals. The highest frequencies were observed in children. In a population of } \\ & \text { SARS-CoV-2-uninfected healthy children between the ages of } 1 \text { and } 16 \text { years, at least } 21 \text { of }\end{aligned}$ 48 samples scored positively for SARS-CoV-2 S-specific IgG. Anti-S2 antibodies from SARS-CoV-2-uninfected patients exhibited neutralizing activity against SARS-CoV-2.

Anti-SARS-Cov-2 antibodies within IVIG preparations: cross-reactivities with seasonal coronaviruses, natural autoimmunity and therapeutic implications.

Dalakas et al. found that the majority of tested, pre-pandemic IVIG preparations (immunoglobulins from pooled serum samples) contained antibodies that cross-reacted with SARS-CoV-2.

Dalakas et al.

Cross-reactive serum and memory B cell

Song et al. endemic coronavirus infection.

Song et al. observed minimal or no reactivity to SARS-CoV-2 S among pre-pandemic samples. 
Altogether, the studies of SARS-CoV-2-unexposed persons revealed antibody responsiveness toward SARS-CoV-2 with variable frequencies and binding targets. Many studies were with sera, not monoclonal antibodies, in which case it was surmised, but unproven, that individual antibodies bound both common cold HCoVs and SARS-CoV-2, and that the induction of cross-reactive antibodies was due to previous common cold $\mathrm{HCoV}$ exposures. As an alternative explanation, one author suggested that pre-pandemic antibodies responsive to SARS-CoV-2 might have been induced by other antigens such as those in vaccines for diptheria, polio, and tetanus (DPT) [64].

\section{Upregulation of Cross-Reactive Antibodies after SARS-CoV-2 Infections}

As a parallel strategy to the analyses of samples from SARS-CoV-2-unexposed individuals, researchers asked if SARS-CoV-2-exposed individuals (often identified by a positive SARS-CoV-2 polymerase chain reaction, PCR), when compared to SARS-CoV-2-unexposed individuals, exhibited enhanced responses to the common cold HCoVs. Samples of reports and results are listed in Table 2. As demonstrated, immune responses toward the common cold HCoVs were often upregulated following SARS-CoV-2 exposures suggesting that responses were cross-reactive. Again, antibody targets were often N and S2.

The combined results from testing pre-pandemic sera, post-pandemic sera, and monoclonals told a consistent story. They showed that certain antibodies could cross-react, at least weakly, between SARS-CoV-2 and common cold $\mathrm{HCoV}$ proteins and that $\mathrm{S}$ (particularly S2, a potential target of neutralization) and $\mathrm{N}$ proteins were common targets of antibody binding. 
Table 2. Antibody responses in patients with COVID-19.

Authors Manuscript Title

$S$ protein-reactive IgG and memory B cell

Nguyen-Contant et al. production after human SARS-CoV-2 infection includes broad reactivity to the S2 subunit.

Shrock et al.

Viral epitope profiling of COVID-19 patients reveals cross-reactivity and correlates of severity.

Pediatric Severe Acute Respiratory Syndrome

Yonker et al. Coronavirus 2 (SARS-CoV-2): Clinical Presentation, Infectivity, and Immune Responses.

Cross-reactive serum and memory B cell responses to spike protein in SARS-CoV-2 and endemic coronavirus infection.

Song et al.

Seasonal human coronavirus antibodies are boosted

Anderson et al. with protection.

\section{Results}

Paper

Nguyen-Contant et al. observed upregulation of antibodies toward common cold HCoVs in COVID-19 patients compared to SARS-CoV-2-unexposed controls. As an example, IgG titers toward OC43 S were higher in SARS-CoV-2 convalescent patients compared to unexposed donors. Both S2- and N-specific responses were significantly upregulated in the SARS-CoV-2 -exposed blood donors.

Shrock et al. used VirScan technology to identify peptide-specific responses that increased in SARS-CoV-2-exposed individuals. They observed elevated antibodies toward peptides in S and N. For example, antibodies toward SARS-CoV-2 S peptides that spanned the region of amino acids 811-830 were increased. An 11 amino acid stretch in this region was found to be

highly conserved between SARS-CoV-2 and all four of the common cold HCoVs. This

peptide overlapped with the S2 fusion peptide. Additionally, antibodies that targeted another region of the SARS-CoV-2 S2 peptide, amino acids 1144-1163, increased in

SARS-CoV-2-exposed individuals compared to unexposed donors. A ten amino acid stretch within this sequence was well matched between SARS-CoV-2 and OC43.

Yonker et al. identified improved responses to the RBD of common cold HCoVs (229E, NL63, HKU1, and OC43) in children who were suffering MIS-C due to SARS-CoV2. However, these children also experienced increases in antibodies toward respiratory syncytial virus and influenza virus, suggesting that B cells were activated non-specifically.

Authors suggested that pre-existing cross-reactive memory B cells were activated during SARS-CoV-2 infection. Authors identified elevated antibodies toward the HKU1 and NL63 S proteins in SARS-CoV-2-exposed individuals compared to pre-pandemic samples. They also characterized a cross-reactive, S2-specific monoclonal antibody with neutralizing activity. Specifically, single-particle negative stain electron microscopy was used to show that monoclonal CC 40.8 bound to the HKU1 S trimer near the bottom of the S2 domain.

Anderson et al. tested samples from 27 hospitalized COVID-19 patients longitudinally and observed increases in antibodies that recognized the S protein of OC43 and SARS-CoV-2 over the course of hospitalization. 


\section{Testing Cross-Reactive S1 Antibody Induction in a Controlled Research Setting}

Cross-reactive antibodies between the common cold HCoV S1 and SARS-CoV-2 S1 in human sera are difficult to detect $[66,67]$. The interpretation of these results is complicated, because the full histories of pathogen exposures are unknown. The timing and origins of immune responses may be incorrectly assigned. Co-infections further complicate data interpretations. Small animals, although non-identical to humans, provide a controlled setting for analyses of immune responses. Mice, like humans, have sophisticated immunoglobulin loci comprising variable $(\mathrm{V})$, diversity $(\mathrm{D})$, joining $(\mathrm{J})$, and constant $(\mathrm{C})$ region genes, and generate an extraordinary number of unique antibodies via gene segment recombination. In numerous instances, murine antibodies have been instrumental in the definition of viral protein structures, antibody targets, and amino acid sequences that are pertinent to antibody cross-reactivity [68-70]. We thus designed controlled murine experiments to test whether cross-reactive SARS-CoV-2 S1-specific antibodies could be deliberately induced by immunizations with $\mathrm{S} 1$ from each of the common cold HCoVs.

Groups of C57BL/ 6 mice were immunized with S1, either from SARS-CoV-2 or from each of the four common cold HCoVs (OC43, NL63, 229E, and HKU1). A separate set of mice received the RBD of SARS-CoV-2, and control mice received phosphate buffered saline (PBS) with no antigen. Three mice per group were used in each of two independent experiments. The first immunization was with $5 \mu \mathrm{g}$ protein emulsified in complete Freunds adjuvant (CFA, 1:1, Thermo Scientific), administered in $100 \mu \mathrm{L}$ intraperitoneally (IP). A booster 21 days later was with $5 \mu \mathrm{g}$ of the same protein in incomplete Freunds adjuvant (IFA, Thermo Scientific). Mice were bled on day 15 post-boost and sera were stored at $-20^{\circ} \mathrm{C}$ prior to testing in an ELISA.

ELISAs were performed with mouse sera to test for binding toward the array of S1 proteins (excluding the RBD of SARS-CoV-2). Representative results are shown in Figure 1 with serum from each mouse (listed on the $X$ axis) tested for binding with each S1 protein. ELISA plates were coated with S1 proteins from A. SARS-CoV-2, B. HKU1, C. OC43, D. NL63, and E. 229E. While each S1 vaccine generated antibody responses toward the homologous antigen, the cross-binding potentials were poor in most instances.

Mice vaccinated with the RBD of SARS-CoV-2 generated a response, albeit weak, toward the SARS-CoV-2 S1 recombinant (Figure 1A). Mice primed with S1 proteins of OC43, NL63, 229E, and HKU1 all exhibited a poor response toward SARS-CoV-2 S1 (Figure 1A). The HKU1 S1 protein induced significant antibodies toward OC43 S1 in some (but not all) mice, reflecting similarities between these two betacoronaviruses (Figure 1C). Similar to previous findings, we found that OC43 and 229E S proteins were poorly related serologically [19]. Our finding of poor induction of SARS-CoV-2 S1-specific antibodies by common cold HCoV S1 proteins extended the finding of Kim et al. who demonstrated that SARS-CoV-2 S1-primed mice generated negligible responses toward NL63 [71].

When reviewing in vitro data, we emphasize that assay targets were recombinant, truncated and secreted proteins that did not fully represent the three-dimensional and four-dimensional (3D and 4D) structures of S1 in an infected cell. The assays were therefore unlikely to detect every S1-specific antibody. Nonetheless, the results supported the use of $\mathrm{S} 1$ sequences in assays designed to diagnose SARS-CoV-2 infections specifically [72]. The results also supported previous literature showing that cross-reactive antibody responses between S1 proteins of SARS-CoV-2 and the common cold HCoVs were difficult to detect. 


\section{A. SARS-CoV-2 ELISA}

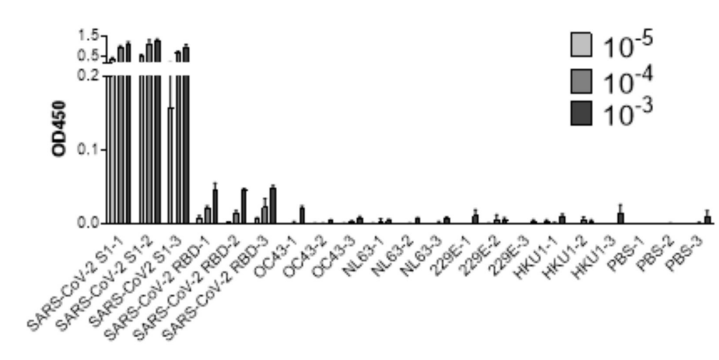

B. HKU1 ELISA

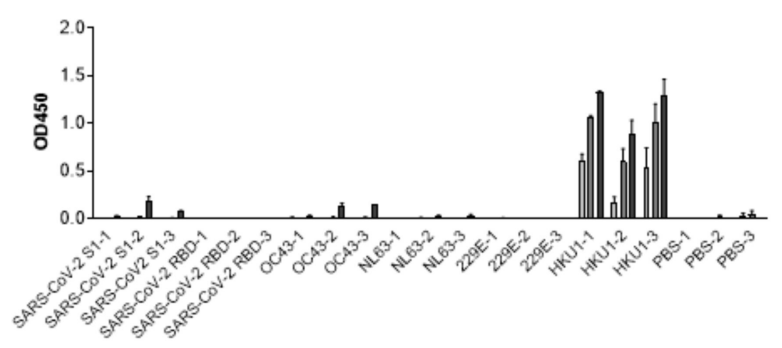

D. NL63 ELISA

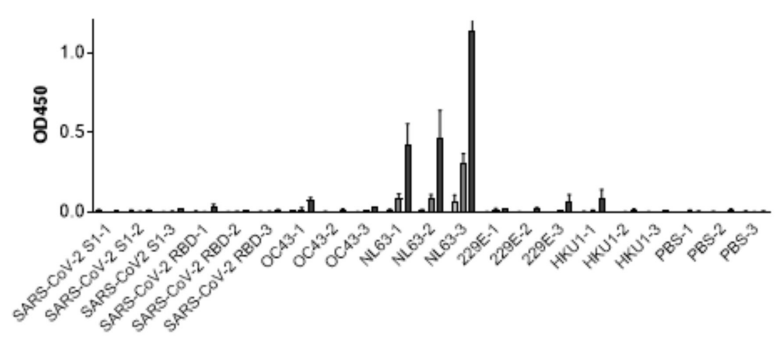

C. OC43 ELISA

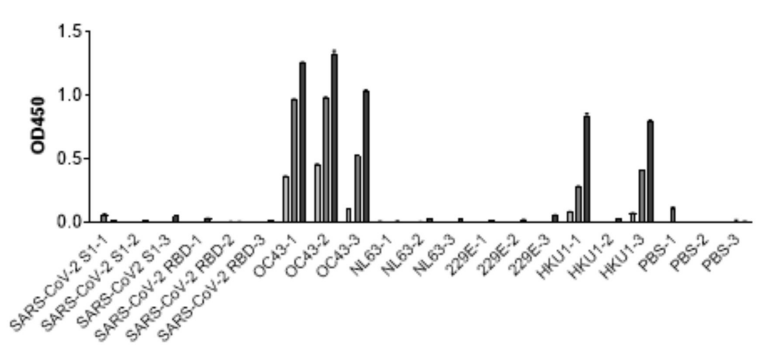

E. 229E ELISA

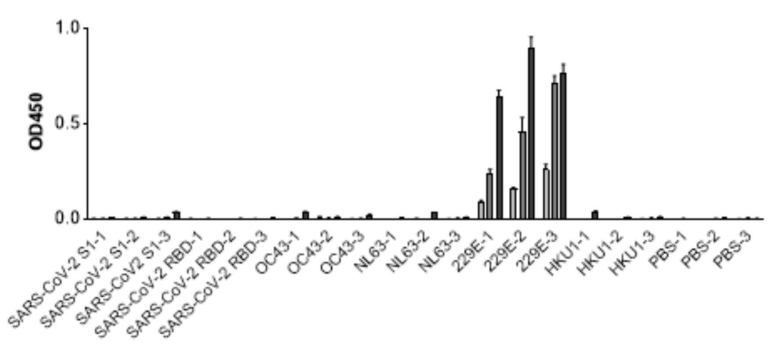

Figure 1. Poor cross-reactivity between recombinant S1 proteins from SARS-CoV-2 and common cold HCoVs. Method: Mice were female C57Bl/6J from Jackson Laboratories. Animal experiments were reviewed and approved by the St. Jude Institutional Animal Care and Use Committee (IACUC). Individual mouse sera ( $X$ axes) were named by immunogen and mouse number (1,2, or 3, for each of three mice per immunization group). All antigens were S1 except for the SARS-CoV-2RBD. PBS-primed mice were negative controls. Recombinant spike proteins used for priming and ELISAs were obtained from SINO Biologicals and were produced from HEK293 cells (unless indicated below). Proteins were tagged at the C terminus. Proteins included common cold HCoV-HKU1 (40021 V08H, S1 amino acids (aa) Met1-Arg760 with a polyhistidine (His) tag), 2019nCoV (SARS-CoV-2, 40591 V08H, S1 a.a. Val16-Arg685, His-tag), common cold HCoV-OC43 (40607 V08B, S1 and S2 aa Met1-Pro1304, expressed in baculovirus insect cells), common cold HCoV-NL63 (40600 V08H, S1 aa Cys19-Val717, His tag) common cold HCoV-229E Spike S1 (40601 V08H, S1 aa Cys16-Asn536, His tag), and 2019nCoV (SARS-CoV-2) RBD (40592 V05H, S1 aa arg319-phe541, tagged with the Fc region of mouse IgG1). To perform the ELISA, each S1 protein (excluding the SARS-CoV-2 RBD, $40592 \mathrm{~V} 05 \mathrm{H})$ was coated separately overnight $(0.5 \mu \mathrm{g} / \mathrm{mL}$ in $100 \mu \mathrm{L}$ PBS) on flat bottomed 96 well plates. Plates were washed three times with Dulbecco's phosphate buffered saline (DPBS) and blocked with $100 \mu \mathrm{L}$ $1 \%$ bovine serum albumin (BSA) for $1 \mathrm{~h}$ at $37^{\circ} \mathrm{C}$. Mouse sera were diluted in 1\% BSA, 0.05\% TWEEN 20 in PBS and $100 \mu \mathrm{L}$ were added per well. Plates were incubated for $30 \mathrm{~min}$ at $37{ }^{\circ} \mathrm{C}$ and washed with $0.05 \%$ TWEEN 20 in PBS. Then $100 \mu \mathrm{L}$ goat anti-mouse IgG H + L antibody conjugated to horse radish peroxidase (HRP, Southern Biotechnologies 1031-05; diluted 1:5000 in $1 \%$ BSA in PBS) were added and incubated for $30 \mathrm{~min}$ at $37^{\circ} \mathrm{C}$. Plates were washed with $0.05 \%$ TWEEN 20 in PBS. Plates then received $100 \mu \mathrm{L}$ TMB substrate (KPL) and reactions were stopped with $100 \mu \mathrm{L} 1 \mathrm{M} \mathrm{H}_{3} \mathrm{PO}_{4}$ within 5 min of reagent addition. Plates were read within 15-20 min after reactions were stopped. $\mathrm{OD}_{450} \mathrm{~nm}$ readings are shown with serum dilutions of 1:1000, 1:10,000 and 1:100,000 (see graph legend). Plates were coated with S1 proteins from (A) SARS-CoV-2, (B) HKU1, (C) OC43, (D) NL63, and (E) 229E. 


\section{T Cells Cross-React with Common Cold HCoVs and SARS-CoV-2}

A number of cross-reactive $\mathrm{T}$ cell responses and epitopes have been mapped between SARS-CoV-2 and the common cold HCoVs [73-79]. Le Bert et al. [75], for example, reported frequent $\mathrm{T}$ cell responses to SARS-CoV-2 non-structural and $\mathrm{N}$ proteins among SARS$\mathrm{CoV}$-2-unexposed donors. As was the case for antibodies, reports of virus-specific $\mathrm{T}$ cell frequencies have varied between studies based on host group and assay. Both CD8+ and $\mathrm{CD} 4+\mathrm{T}$ cell cross-reactive populations have been identified, and for each population, cross-reactive peptide epitopes have been described [73-78,80,81]. T cells may exhibit a variety of effector functions toward SARS-CoV-2 or common cold $\mathrm{HCoVs}$ including the secretion of cytokines/chemokines, the killing of SARS-CoV-2 infected cells (cytotoxic T lymphocyte, CTL), the provision of help by cognate interactions with B cells (T helper [TH] or $\mathrm{T}$ follicular helper [TFH]), and/or the targeted down-regulation of an immune response (Regulatory $\mathrm{T}$ cell, Treg). In some studies, more than $50 \%$ of humans with no known previous exposures to SARS CoV-2 have exhibited T cell reactivity toward SARS-CoV-2 [48]. Cross-reactive T cells, like B cells, were upregulated upon exposures to SARS-CoV-2.

A point to be considered when examining $\mathrm{T}$ cells is that 'help' from a SARS-CoV-2 specific $T$ cell can be relayed to a SARS-CoV-2-specific B cell when B cell and T cell epitopes do not match. For example, a T cell that recognizes an N peptide of SARS-CoV-2 could suffice to 'help' a B cell that produces S-specific, neutralizing antibodies. This is because a B cell with antibodies that bind viral surface proteins (e.g., S) can internalize virions and process a variety of viral peptides (from both internal and external viral proteins) for presentation with major histocompatibility complex (MHC) class II proteins on the B cell surface. A T cell receptor that recognizes any one of these viral peptides (e.g., $\mathrm{N}$ ) might then deliver cognate $\mathrm{T}$ cell help to an S-specific B cell [82].

\section{Influence of Cross-Reactive Immune Responses on SARS-CoV-2 Disease in Humans}

We ask, what is the outcome of human SARS-CoV-2 infections in the context of pre-existing immunity toward a cross-reactive epitope on common cold HCoVs? Do prepandemic cross-reactive immune responses confer benefit or harm? The results have, again, been mixed.

Anderson et al. [46] suggested that pre-pandemic SARS-CoV-2 cross-reactive antibodies were not associated with reducing SARS-CoV-2 infections. This conclusion was based on the finding that groups of SARS-CoV-2-infected and uninfected persons had similar SARS-CoV-2-specific IgG levels when their banked pre-pandemic samples were tested. The authors acknowledged that results were not definitive due to experimental weaknesses. Weaknesses included small group sizes, unknown SARS-CoV-2 exposure frequencies (particularly in the uninfected group), low frequencies of S-specific, cross-reactive antibodies in pre-pandemic samples, and large time differences between the collection of pre-pandemic samples and any subsequent, potential SARS-CoV-2 exposures.

In contrast to the results of Anderson et al., Sagar et al. described an improved outcome for individuals who had a recent, documented history of a common cold $\mathrm{HCoV}$ infection prior to experiencing COVID-19, compared to controls [83]. Specifically, patients with a recent, documented history of common cold $\mathrm{HCoV}$ infections, when hospitalized with COVID-19, had lower rates of intensive care unit admissions and had improved rates of survival. These results suggested that pre-existing immune responses toward common cold $\mathrm{HCoV}$ conferred a degree of protection against SARS-CoV-2.

Another indication that the common cold $\mathrm{HCoVs}$ may provide a degree of protection against SARS-CoV-2 is that in low-income, high-density regions, where common cold $\mathrm{HCoV}$ exposures are presumed to be high, there are relatively high rates of SARS-CoV-2 infections, but low rates of serious disease. For example, in Mumbai, India SARS-CoV-2 infection rates were higher in slums compared to non-slums, but fatality rates due to SARS-CoV-2 were lower in slums compared to non-slums. It has also been observed that poor, highly populated countries have suffered fewer deaths from SARS-CoV-2 per million individuals compared to Western nations $[84,85]$. 
Might cross-reactive immune responses cause harm? In the dengue virus field, preexisting responses toward non-identical viral variants have in some cases worsened disease due to antibody dependent enhancement (ADE) [86]. It is possible that a similar outcome could be experienced in the context of common cold HCoV and SARS-CoV-2 infections [87]. Pre-existing immunity toward a common cold $\mathrm{HCoV}$ may be of particular concern in the context of MIS-C, when children suffer disease due to an over-active immune response toward SARS-CoV-2. When a SARS-CoV-2 exposure occurs, as with any virus, the immune response must achieve a fine balance to support virus clearance without immunopathology. When high-quality pre-existing immunity exists, B cells and T cells may clear virus in the URT before virus amplifies and progresses to the LRT. In this case, the virus infection may be asymptomatic and go unnoticed. In contrast, if the immune response is delayed and virus exists at high titers in the LRT, immune effectors can be detrimental. In this instance, a vigorous and rapid immune response may cause a cytokine storm and irreparable damage to the airways even after replication-competent virus has been cleared. A most notable illustration of immunopathology in the context of a respiratory virus infection was in the 1960s: a formalin-treated respiratory syncytial virus (RSV) vaccine was tested in children, but failed to induce neutralizing antibodies. Instead, immune responses caused significant morbidity and two deaths among vaccinated participants when participants were naturally exposed to RSV at a later date. Researchers are currently debating the extent of immunopathology in patients with COVID-19. Some assume that cytokine storms are prominent. Others argue that few patients with COVID-19 exhibit cytokine profiles indicative of a cytokine storm and that COVID-19 patients are much less inflamed than patients with influenza. Arguments regarding disease symptoms fuel additional debates regarding COVID-19 treatments, as clinicians strive to support virus clearance without immunopathology [88].

One difficulty with human studies is the failure to detect all SARS-CoV-2 exposures. If an individual is protected from SARS-CoV-2 due to a previous exposure to a common cold $\mathrm{HCoV}$, a subsequent SARS-CoV-2 exposure may go unnoticed. Experimental human challenges with common cold HCoVs have already been performed [89,90] and new studies of experimental human SARS-CoV-2 challenges have recently received regulatory approval in the United Kingdom [91]. Perhaps the results from controlled challenge studies in small animal models and human adults [92-94] will help better define if/how crossreactive responses, induced by the common cold HCoVs influence SARS-CoV-2 infections and disease.

\section{Why Has the Study of Cross-Reactive Immune Responses Yielded Conflicting Messages?}

Researchers have often reported contrasting results regarding measurement of crossreactivity between SARS-CoV-2 and the common cold HCoVs. Some authors have detected no or few cross-reactive antibodies, whereas others have identified antibodies and precise epitope targets. Some authors have observed neutralization capacities and others have not. These discrepancies are a consequence of differences in research subjects (inclusive of small research animals, non-human primates, and humans of various ages, sexes and geographical locations), assays and assay cut-off values. Assays have not yet been standardized, and can vary between laboratories with regard to target antigens, developing reagents, protocols, and interpretations. When designing immune assays, the integrity of target epitopes must be considered. Antibodies often respond to three- or four-dimensional structures that cannot be matched by truncated peptide fragments [69]. For T cell responses, the position of a target peptide within its viral protein and antigen presentation events must also be considered. Even when a target peptide is known to exist within a viral protein, the success of antigen processing for $\mathrm{T}$ cell recognition will depend on peptide context [95]. Having these caveats in mind, researchers must view published scientific data with an understanding that assessments of cross-reactive antibodies, $\mathrm{T}$ cells, and effector potentials remain incomplete. 


\section{Conclusions}

Research of cross-reactive antibodies between common cold HCoVs and SARS-CoV-2 has yielded mixed results. In a significant fraction of SARS-CoV-2-unexposed humans, cross-reactive $\mathrm{T}$ cells and antibodies that recognized both common cold HCoVs and SARS$\mathrm{CoV}-2$ were found. Additionally, when humans were naturally exposed to SARS-CoV2 , there were increases in immune responses toward the common cold HCoVs. Crossreactive antibodies were frequently observed toward S2 (in some cases associated with neutralizing function) and $\mathrm{N}$, but rarely $\mathrm{S} 1$. When mice were deliberately immunized with $\mathrm{S} 1$ recombinant proteins, the induction of cross-reactive antibody responses was poor. The presence of cross-reactive antibody responses and cross-reactive $\mathrm{T}$ cell responses in humans may well impact diagnoses, prophylaxes, treatments, and outcomes of SARS-CoV2 infections.

Author Contributions: Conceptualization, J.L.H.; methodology, R.E.S. and J.L.H.; investigation, R.E.S.; resources, J.L.H.; writing—original draft preparation, J.L.H.; writing—review and editing, R.E.S. and J.L.H. All authors have read and agreed to the published version of the manuscript.

Funding: This study was supported in part by the National Institutes of Health (NIH), National Cancer Institute P30CA21765, ALSAC, and by the Collaborative Influenza Vaccine Innovation Centers (CIVIC) contract by the National Institute of Allergy and Infectious Diseases, a component of the $\mathrm{NIH}$, Department of Health and Human Services, under contract 75N93019C00052.

Data Availability Statement: Additional data may be requested from authors.

Conflicts of Interest: The authors declare no conflict of interest.

$\begin{array}{ll}\text { Abbreviations } \\ \text { SARS-CoV-2 } & \text { severe acute respiratory syndrome coronavirus 2; } \\ \text { HCoV } & \text { human coronavirus; } \\ \text { MIS-C } & \text { multisystem inflammatory syndrome in children; } \\ \text { RBD } & \text { receptor binding domain; } \\ \text { ACE2 } & \text { angiotensin-converting enzyme 2 }\end{array}$

\section{References}

1. Zhou, P.; Yang, X.L.; Wang, X.G.; Hu, B.; Zhang, L.; Zhang, W.; Si, H.R.; Zhu, Y.; Li, B.; Huang, C.L.; et al. A pneumonia outbreak associated with a new coronavirus of probable bat origin. Nature 2020, 579, 270-273. [CrossRef]

2. Lu, R.; Zhao, X.; Li, J.; Niu, P.; Yang, B.; Wu, H.; Wang, W.; Song, H.; Huang, B.; Zhu, N.; et al. Genomic characterisation and epidemiology of 2019 novel coronavirus: Implications for virus origins and receptor binding. Lancet 2020, 395, 565-574. [CrossRef]

3. Johns Hopkins University and Medicine. Coronavirus Resource Center. Available online: https://coronavirus.jhu.edu (accessed on 6 June 2021).

4. Xiao, F.; Tang, M.; Zheng, X.; Liu, Y.; Li, X.; Shan, H. Evidence for Gastrointestinal Infection of SARS-CoV-2. Gastroenterology 2020, 158, 1831-1833.e3. [CrossRef]

5. Coronavirus Disease 2019. COVID-19 in Children and Teens, Updated 18 December 2020. Available online: www.cdc.gov (accessed on 25 February 2021).

6. Guruprasad, L. Human coronavirus spike protein-host receptor recognition. Prog. Biophys. Mol. Biol. 2020. [CrossRef] [PubMed]

7. Naqvi, A.A.T.; Fatima, K.; Mohammad, T.; Fatima, U.; Singh, I.K.; Singh, A.; Atif, S.M.; Hariprasad, G.; Hasan, G.M.; Hassan, M.I. Insights into SARS-CoV-2 genome, structure, evolution, pathogenesis and therapies: Structural genomics approach. Biochim Biophys. Acta Mol. Basis Dis. 2020, 1866, 165878. [CrossRef] [PubMed]

8. Mandala, V.S.; McKay, M.J.; Shcherbakov, A.A.; Dregni, A.J.; Kolocouris, A.; Hong, M. Structure and drug binding of the SARS-CoV-2 envelope protein transmembrane domain in lipid bilayers. Nat. Struct. Mol. Biol. 2020, 27, 1202-1208. [CrossRef]

9. Weiss, S.R.; Navas-Martin, S. Coronavirus pathogenesis and the emerging pathogen severe acute respiratory syndrome coronavirus. Microbiol. Mol. Biol. Rev. 2005, 69, 635-664. [CrossRef] [PubMed]

10. Widge, A.T.; Rouphael, N.G.; Jackson, L.A.; Anderson, E.J.; Roberts, P.C.; Makhene, M.; Chappell, J.D.; Denison, M.R.; Stevens, L.J.; Pruijssers, A.J.; et al. Durability of Responses after SARS-CoV-2 mRNA-1273 Vaccination. N. Engl. J. Med. 2021, 384, 80-82. [CrossRef]

11. Baden, L.R.; El Sahly, H.M.; Essink, B.; Kotloff, K.; Frey, S.; Novak, R.; Diemert, D.; Spector, S.A.; Rouphael, N.; Creech, C.B.; et al. Efficacy and Safety of the mRNA-1273 SARS-CoV-2 Vaccine. N. Engl. J. Med. 2020. [CrossRef] 
12. Walsh, E.E.; Frenck, R.W., Jr.; Falsey, A.R.; Kitchin, N.; Absalon, J.; Gurtman, A.; Lockhart, S.; Neuzil, K.; Mulligan, M.J.; Bailey, R.; et al. Safety and Immunogenicity of Two RNA-Based Covid-19 Vaccine Candidates. N. Engl. J. Med. 2020. [CrossRef]

13. Polack, F.P.; Thomas, S.J.; Kitchin, N.; Absalon, J.; Gurtman, A.; Lockhart, S.; Perez, J.L.; Perez Marc, G.; Moreira, E.D.; Zerbini, C.; et al. Safety and Efficacy of the BNT162b2 mRNA Covid-19 Vaccine. N. Engl. J. Med. 2020, 383, 2603-2615. [CrossRef]

14. Rawat, K.; Kumari, P.; Saha, L. COVID-19 vaccine: A recent update in pipeline vaccines, their design and development strategies. Eur. J. Pharm. 2021, 892, 173751. [CrossRef]

15. Walensky, R.P.; Walke, H.T.; Fauci, A.S. SARS-CoV-2 Variants of Concern in the United States-Challenges and Opportunities. JAMA 2021, 325, 1037-1038. [CrossRef]

16. Monto, A.S.; DeJonge, P.M.; Callear, A.P.; Bazzi, L.A.; Capriola, S.B.; Malosh, R.E.; Martin, E.T.; Petrie, J.G. Coronavirus Occurrence and Transmission Over 8 Years in the HIVE Cohort of Households in Michigan. J. Infect. Dis. 2020, 222, 9-16. [CrossRef] [PubMed]

17. Li, P.; Liu, J.; Ma, Z.; Bramer, W.M.; Peppelenbosch, M.P.; Pan, Q. Estimating Global Epidemiology of Low-Pathogenic Human Coronaviruses in Relation to the COVID-19 Context. J. Infect. Dis. 2020, 222, 695-696. [CrossRef] [PubMed]

18. Gorse, G.J.; Patel, G.B.; Vitale, J.N.; O'Connor, T.Z. Prevalence of antibodies to four human coronaviruses is lower in nasal secretions than in serum. Clin. Vaccine Immunol. 2010, 17, 1875-1880. [CrossRef] [PubMed]

19. Van der Hoek, L. Human coronaviruses: What do they cause? Antivir. Ther. 2007, 12, 651-658.

20. Falsey, A.R.; Walsh, E.E.; Hayden, F.G. Rhinovirus and coronavirus infection-associated hospitalizations among older adults. J. Infect. Dis. 2002, 185, 1338-1341. [CrossRef]

21. Kronvall, G.; Nordenfelt, E. On the history of human coronaviruses. APMIS 2021. [CrossRef]

22. Hamre, D.; Procknow, J.J. A new virus isolated from the human respiratory tract. Proc. Soc. Exp. Biol. Med. 1966, 121, 190-193. [CrossRef] [PubMed]

23. Hofmann, H.; Pyrc, K.; van der Hoek, L.; Geier, M.; Berkhout, B.; Pohlmann, S. Human coronavirus NL63 employs the severe acute respiratory syndrome coronavirus receptor for cellular entry. Proc. Natl. Acad. Sci. USA 2005, 102, 7988-7993. [CrossRef]

24. van der Hoek, L.; Pyrc, K.; Berkhout, B. Human coronavirus NL63, a new respiratory virus. FEMS Microbiol. Rev. 2006, 30, 760-773. [CrossRef] [PubMed]

25. van der Hoek, L.; Pyrc, K.; Jebbink, M.F.; Vermeulen-Oost, W.; Berkhout, R.J.; Wolthers, K.C.; Wertheim-van Dillen, P.M.; Kaandorp, J.; Spaargaren, J.; Berkhout, B. Identification of a new human coronavirus. Nat. Med. 2004, 10, 368-373. [CrossRef]

26. Hoorn, B.; Tyrrell, D.A. On the Growth of Certain "Newer" Respiratory Viruses in Organ Cultures. Br. J. Exp. Pathol. 1965, 46, 109-118.

27. Tyrrell, D.A.; Bynoe, M.L. Cultivation of a Novel Type of Common-Cold Virus in Organ Cultures. Br. Med. J. 1965, 1, 1467-1470. [CrossRef]

28. Tyrrell, D.A.; Almeida, J.D. Direct electron-microscopy of organ culture for the detection and characterization of viruses. Arch. Gesamte Virusforsch 1967, 22, 417-425. [CrossRef]

29. Almeida, J.D.; Tyrrell, D.A. The morphology of three previously uncharacterized human respiratory viruses that grow in organ culture. J. Gen. Virol. 1967, 1, 175-178. [CrossRef]

30. Hoorn, B.; Tyrrell, D.A. A new virus cultivated only in organ cultures of human ciliated epithelium. Arch. Gesamte Virusforsch 1966, 18, 210-225. [CrossRef] [PubMed]

31. Hoorn, B.; Tyrrell, D.A. Organ cultures in virology. Prog. Med. Virol 1969, 11, 408-450. [PubMed]

32. Bruckova, M.; McIntosh, K.; Kapikian, A.Z.; Chanock, R.M. The adaptation of two human coronavirus strains (OC38 and OC43) to growth in cell monolayers. Proc. Soc. Exp. Biol. Med. 1970, 135, 431-435. [CrossRef] [PubMed]

33. McIntosh, K.; Bruckova, M.; Kapikian, A.Z.; Chanock, R.J.; Turner, H. Studies on new virus isolates recovered in tracheal organ culture. Ann. N. Y. Acad. Sci. 1970, 174, 983-989. [CrossRef]

34. McIntosh, K.; Dees, J.H.; Becker, W.B.; Kapikian, A.Z.; Chanock, R.M. Recovery in tracheal organ cultures of novel viruses from patients with respiratory disease. Proc. Natl. Acad. Sci. USA 1967, 57, 933-940. [CrossRef]

35. McIntosh, K.; Becker, W.B.; Chanock, R.M. Growth in suckling-mouse brain of "IBV-like" viruses from patients with upper respiratory tract disease. Proc. Natl. Acad. Sci. USA 1967, 58, 2268-2273. [CrossRef] [PubMed]

36. Pyrc, K.; Berkhout, B.; van der Hoek, L. Identification of new human coronaviruses. Expert Rev. Anti Infect. Ther. 2007, 5, 245-253. [CrossRef]

37. Lau, S.K.; Woo, P.C.; Yip, C.C.; Tse, H.; Tsoi, H.W.; Cheng, V.C.; Lee, P.; Tang, B.S.; Cheung, C.H.; Lee, R.A.; et al. Coronavirus HKU1 and other coronavirus infections in Hong Kong. J. Clin. Microbiol. 2006, 44, 2063-2071. [CrossRef] [PubMed]

38. Woo, P.C.; Lau, S.K.; Chu, C.M.; Chan, K.H.; Tsoi, H.W.; Huang, Y.; Wong, B.H.; Poon, R.W.; Cai, J.J.; Luk, W.K.; et al. Characterization and complete genome sequence of a novel coronavirus, coronavirus HKU1, from patients with pneumonia. $J$. Virol. 2005, 79, 884-895. [CrossRef]

39. Pyrc, K.; Berkhout, B.; van der Hoek, L. The novel human coronaviruses NL63 and HKU1. J. Virol. 2007, 81, 3051-3057. [CrossRef]

40. Gussow, A.B.; Auslander, N.; Faure, G.; Wolf, Y.I.; Zhang, F.; Koonin, E.V. Genomic determinants of pathogenicity in SARS-CoV-2 and other human coronaviruses. Proc. Natl. Acad. Sci. USA 2020, 117, 15193-15199. [CrossRef] [PubMed]

41. Hamre, D.; Kindig, D.A.; Mann, J. Growth and intracellular development of a new respiratory virus. J. Virol. 1967, 1, 810-816. [CrossRef] [PubMed]

42. Fouchier, R.A.; Hartwig, N.G.; Bestebroer, T.M.; Niemeyer, B.; de Jong, J.C.; Simon, J.H.; Osterhaus, A.D. A previously undescribed coronavirus associated with respiratory disease in humans. Proc. Natl. Acad. Sci. USA 2004, 101, 6212-6216. [CrossRef] 
43. Corman, V.M.; Baldwin, H.J.; Tateno, A.F.; Zerbinati, R.M.; Annan, A.; Owusu, M.; Nkrumah, E.E.; Maganga, G.D.; Oppong, S.; Adu-Sarkodie, Y.; et al. Evidence for an Ancestral Association of Human Coronavirus 229E with Bats. J. Virol. 2015, 89, 11858-11870. [CrossRef]

44. Vijgen, L.; Keyaerts, E.; Moes, E.; Thoelen, I.; Wollants, E.; Lemey, P.; Vandamme, A.M.; Van Ranst, M. Complete genomic sequence of human coronavirus OC43: Molecular clock analysis suggests a relatively recent zoonotic coronavirus transmission event. J. Virol. 2005, 79, 1595-1604. [CrossRef]

45. Cueno, M.E.; Imai, K. Structural Comparison of the SARS CoV 2 Spike Protein Relative to Other Human-Infecting Coronaviruses. Front. Med. 2020, 7, 594439. [CrossRef] [PubMed]

46. Anderson, E.M.; Goodwin, E.C.; Verma, A.; Arevalo, C.P.; Bolton, M.J.; Weirick, M.E.; Gouma, S.; McAllister, C.M.; Christensen, S.R.; Weaver, J.; et al. Seasonal human coronavirus antibodies are boosted upon SARS-CoV-2 infection but not associated with protection. medRxiv 2020. [CrossRef]

47. Khan, S.; Nakajima, R.; Jain, A.; de Assis, R.R.; Jasinskas, A.; Obiero, J.M.; Adenaiye, O.; Tai, S.; Hong, F.; Milton, D.K.; et al. Analysis of Serologic Cross-Reactivity Between Common Human Coronaviruses and SARS-CoV-2 Using Coronavirus Antigen Microarray. bioRxiv 2020. [CrossRef]

48. Doshi, P. Covid-19: Do many people have pre-existing immunity? BMJ 2020, 370, m3563. [CrossRef] [PubMed]

49. Ng, K.W.; Faulkner, N.; Cornish, G.H.; Rosa, A.; Harvey, R.; Hussain, S.; Ulferts, R.; Earl, C.; Wrobel, A.G.; Benton, D.J.; et al. Preexisting and de novo humoral immunity to SARS-CoV-2 in humans. Science 2020, 370, 1339-1343. [CrossRef]

50. Long, Q.X.; Liu, B.Z.; Deng, H.J.; Wu, G.C.; Deng, K.; Chen, Y.K.; Liao, P.; Qiu, J.F.; Lin, Y.; Cai, X.F.; et al. Antibody responses to SARS-CoV-2 in patients with COVID-19. Nat. Med. 2020, 26, 845-848. [CrossRef]

51. Shiakolas, A.R.; Kramer, K.J.; Wrapp, D.; Richardson, S.I.; Schafer, A.; Wall, S.; Wang, N.; Janowska, K.; Pilewski, K.A.; Venkat, R.; et al. Cross-reactive coronavirus antibodies with diverse epitope specificities and extra-neutralization functions. bioRxiv 2020. [CrossRef]

52. Wec, A.Z.; Wrapp, D.; Herbert, A.S.; Maurer, D.P.; Haslwanter, D.; Sakharkar, M.; Jangra, R.K.; Dieterle, M.E.; Lilov, A.; Huang, D.; et al. Broad neutralization of SARS-related viruses by human monoclonal antibodies. Science 2020, 369, 731-736. [CrossRef]

53. Laing, E.D.; Sterling, S.L.; Richard, S.A.; Phogat, S.; Samuels, E.C.; Epsi, N.J.; Yan, L.; Moreno, N.; Coles, C.; Mehalko, J.; et al. A betacoronavirus multiplex microsphere immunoassay detects early SARS-CoV-2 seroconversion and controls for pre-existing seasonal human coronavirus antibody cross-reactivity. medRxiv 2020. [CrossRef]

54. Huang, A.T.; Garcia-Carreras, B.; Hitchings, M.D.T.; Yang, B.; Katzelnick, L.C.; Rattigan, S.M.; Borgert, B.A.; Moreno, C.A.; Solomon, B.D.; Trimmer-Smith, L.; et al. A systematic review of antibody mediated immunity to coronaviruses: Kinetics, correlates of protection, and association with severity. Nat. Commun. 2020, 11, 4704. [CrossRef]

55. Song, G.; He, W.T.; Callaghan, S.; Anzanello, F.; Huang, D.; Ricketts, J.; Torres, J.L.; Beutler, N.; Peng, L.; Vargas, S.; et al. Cross-reactive serum and memory B-cell responses to spike protein in SARS-CoV-2 and endemic coronavirus infection. Nat. Commun. 2021, 12, 2938. [CrossRef]

56. Guo, L.; Ren, L.; Yang, S.; Xiao, M.; Chang, D.; Yang, F.; Dela Cruz, C.S.; Wang, Y.; Wu, C.; Xiao, Y.; et al. Profiling Early Humoral Response to Diagnose Novel Coronavirus Disease (COVID-19). Clin. Infect. Dis. 2020, 71, 778-785. [CrossRef] [PubMed]

57. Mveang Nzoghe, A.; Essone, P.N.; Leboueny, M.; Maloupazoa Siawaya, A.C.; Bongho, E.C.; Mvoundza Ndjindji, O.; Avome Houechenou, R.M.; Agnandji, S.T.; Djoba Siawaya, J.F. Evidence and implications of pre-existing humoral cross-reactive immunity to SARS-CoV-2. Immun. Inflamm. Dis. 2021, 9, 128-133. [CrossRef] [PubMed]

58. Ma, Z.; Li, P.; Ji, Y.; Ikram, A.; Pan, Q. Cross-reactivity towards SARS-CoV-2: The potential role of low-pathogenic human coronaviruses. Lancet Microbe 2020, 1, e151. [CrossRef]

59. To, K.K.; Cheng, V.C.; Cai, J.P.; Chan, K.H.; Chen, L.L.; Wong, L.H.; Choi, C.Y.; Fong, C.H.; Ng, A.C.; Lu, L.; et al. Seroprevalence of SARS-CoV-2 in Hong Kong and in residents evacuated from Hubei province, China: A multicohort study. Lancet Microbe 2020, 1, e111-e118. [CrossRef]

60. Shrock, E.; Fujimura, E.; Kula, T.; Timms, R.T.; Lee, I.H.; Leng, Y.; Robinson, M.L.; Sie, B.M.; Li, M.Z.; Chen, Y.; et al. Viral epitope profiling of COVID-19 patients reveals cross-reactivity and correlates of severity. Science 2020, 370. [CrossRef] [PubMed]

61. Tso, F.Y.; Lidenge, S.J.; Pena, P.B.; Clegg, A.A.; Ngowi, J.R.; Mwaiselage, J.; Ngalamika, O.; Julius, P.; West, J.T.; Wood, C. High prevalence of pre-existing serological cross-reactivity against severe acute respiratory syndrome coronavirus-2 (SARS-CoV-2) in sub-Saharan Africa. Int. J. Infect. Dis. 2021, 102, 577-583. [CrossRef] [PubMed]

62. Nguyen-Contant, P.; Embong, A.K.; Kanagaiah, P.; Chaves, F.A.; Yang, H.; Branche, A.R.; Topham, D.J.; Sangster, M.Y. S ProteinReactive IgG and Memory B Cell Production after Human SARS-CoV-2 Infection Includes Broad Reactivity to the S2 Subunit. mBio 2020, 11. [CrossRef] [PubMed]

63. Dalakas, M.C.; Bitzogli, K.; Alexopoulos, H. Anti-SARS-CoV-2 Antibodies Within IVIg Preparations: Cross-Reactivities with Seasonal Coronaviruses, Natural Autoimmunity, and Therapeutic Implications. Front. Immunol 2021, 12, 627285. [CrossRef] [PubMed]

64. Reche, P.A. Potential Cross-Reactive Immunity to SARS-CoV-2 From Common Human Pathogens and Vaccines. Front. Immunol. 2020, 11, 586984. [CrossRef]

65. Yonker, L.M.; Neilan, A.M.; Bartsch, Y.; Patel, A.B.; Regan, J.; Arya, P.; Gootkind, E.; Park, G.; Hardcastle, M.; St John, A.; et al. Pediatric Severe Acute Respiratory Syndrome Coronavirus 2 (SARS-CoV-2): Clinical Presentation, Infectivity, and Immune Responses. J. Pediatr. 2020, 227, P45-52.e5. [CrossRef] 
66. Amanat, F.; Stadlbauer, D.; Strohmeier, S.; Nguyen, T.H.O.; Chromikova, V.; McMahon, M.; Jiang, K.; Arunkumar, G.A.; Jurczyszak, D.; Polanco, J.; et al. A serological assay to detect SARS-CoV-2 seroconversion in humans. Nat. Med. 2020, 26, 1033-1036. [CrossRef]

67. Loos, C.; Atyeo, C.; Fischinger, S.; Burke, J.; Slein, M.D.; Streeck, H.; Lauffenburger, D.; Ryan, E.T.; Charles, R.C.; Alter, G. Evolution of Early SARS-CoV-2 and Cross-Coronavirus Immunity. mSphere 2020, 5. [CrossRef]

68. Caton, A.J.; Brownlee, G.G.; Yewdell, J.W.; Gerhard, W. The antigenic structure of the influenza virus A/PR/8/34 hemagglutinin (H1 subtype). Cell 1982, 31, 417-427. [CrossRef]

69. Gerhard, W.; Yewdell, J.; Frankel, M.E.; Webster, R. Antigenic structure of influenza virus haemagglutinin defined by hybridoma antibodies. Nature 1981, 290, 713-717. [CrossRef]

70. Gerhard, W.; Webster, R.G. Antigenic drift in influenza A viruses I. Selection and characterization of antigenic variants of A/PR/8/34 [H0N1] influenza virus with monoclonal antibodies. J. Exp. Med. 1978, 148, 383-392. [CrossRef]

71. Kim, H.; Seiler, P.; Jones, J.C.; Ridout, G.; Camp, K.P.; Fabrizio, T.P.; Jeevan, T.; Miller, L.A.; Throm, R.E.; Ferrara, F.; et al. Antibody Responses to SARS-CoV-2 Antigens in Humans and Animals. Vaccines 2020, 8, 684. [CrossRef] [PubMed]

72. Premkumar, L.; Segovia-Chumbez, B.; Jadi, R.; Martinez, D.R.; Raut, R.; Markmann, A.; Cornaby, C.; Bartelt, L.; Weiss, S.; Park, Y.; et al. The RBD of the Spike Protein of SARS-Group Coronaviruses Is A Highly Specific Target of SARS-CoV-2 Antibodies But Not Other Pathogenic Human and Animal Coronavirus Antibodies. medRxiv 2020. [CrossRef]

73. Mateus, J.; Grifoni, A.; Tarke, A.; Sidney, J.; Ramirez, S.I.; Dan, J.M.; Burger, Z.C.; Rawlings, S.A.; Smith, D.M.; Phillips, E.; et al. Selective and cross-reactive SARS-CoV-2 T cell epitopes in unexposed humans. Science 2020, 370, 89-94. [CrossRef]

74. Sette, A.; Crotty, S. Pre-existing immunity to SARS-CoV-2: The knowns and unknowns. Nat. Rev. Immunol. 2020, 20, 457-458. [CrossRef]

75. Le Bert, N.; Tan, A.T.; Kunasegaran, K.; Tham, C.Y.L.; Hafezi, M.; Chia, A.; Chng, M.H.Y.; Lin, M.; Tan, N.; Linster, M.; et al. SARS-CoV-2-specific T cell immunity in cases of COVID-19 and SARS, and uninfected controls. Nature 2020, 584, 457-462. [CrossRef] [PubMed]

76. Meckiff, B.J.; Ramirez-Suastegui, C.; Fajardo, V.; Chee, S.J.; Kusnadi, A.; Simon, H.; Grifoni, A.; Pelosi, E.; Weiskopf, D.; Sette, A.; et al. Single-cell transcriptomic analysis of SARS-CoV-2 reactive CD4 (+) T cells. bioRxiv 2020. [CrossRef]

77. Braun, J.; Loyal, L.; Frentsch, M.; Wendisch, D.; Georg, P.; Kurth, F.; Hippenstiel, S.; Dingeldey, M.; Kruse, B.; Fauchere, F.; et al. SARS-CoV-2-reactive T cells in healthy donors and patients with COVID-19. Nature 2020, 587, 270-274. [CrossRef]

78. Saletti, G.; Gerlach, T.; Jansen, J.M.; Molle, A.; Elbahesh, H.; Ludlow, M.; Li, W.; Bosch, B.J.; Osterhaus, A.; Rimmelzwaan, G.F. Older adults lack SARS CoV-2 cross-reactive T lymphocytes directed to human coronaviruses OC43 and NL63. Sci. Rep. 2020, 10, 21447. [CrossRef] [PubMed]

79. Nelde, A.; Bilich, T.; Heitmann, J.S.; Maringer, Y.; Salih, H.R.; Roerden, M.; Lubke, M.; Bauer, J.; Rieth, J.; Wacker, M.; et al. SARS-CoV-2-derived peptides define heterologous and COVID-19-induced T cell recognition. Nat. Immunol. 2021, $22,74-85$. [CrossRef] [PubMed]

80. Schulien, I.; Kemming, J.; Oberhardt, V.; Wild, K.; Seidel, L.M.; Killmer, S.; Sagar; Daul, F.; Salvat Lago, M.; Decker, A.; et al. Characterization of pre-existing and induced SARS-CoV-2-specific CD8(+) T cells. Nat. Med. 2021, 27, 78-85. [CrossRef]

81. Woldemeskel, B.A.; Kwaa, A.K.; Garliss, C.C.; Laeyendecker, O.; Ray, S.C.; Blankson, J.N. Healthy donor T cell responses to common cold coronaviruses and SARS-CoV-2. J. Clin. Investig. 2020, 130, 6631-6638. [CrossRef]

82. Scherle, P.A.; Gerhard, W. Functional analysis of influenza-specific helper T cell clones in vivo. T cells specific for internal viral proteins provide cognate help for B cell responses to hemagglutinin. J. Exp. Med. 1986, 164, 1114-1128. [CrossRef]

83. Sagar, M.; Reifler, K.; Rossi, M.; Miller, N.S.; Sinha, P.; White, L.F.; Mizgerd, J.P. Recent endemic coronavirus infection is associated with less-severe COVID-19. J. Clin. Investig. 2021, 131. [CrossRef] [PubMed]

84. Malani, A.; Shah, D.; Kang, G.; Lobo, G.N.; Shastri, J.; Mohanan, M.; Jain, R.; Agrawal, S.; Juneja, S.; Imad, S.; et al. Seroprevalence of SARS-CoV-2 in slums versus non-slums in Mumbai, India. Lancet Glob. Health 2021, 9, e110-e111. [CrossRef]

85. Capoor, M.N.; Ahmed, F.S.; McDowell, A.; Slaby, O. Is the "Common Cold" Our Greatest Ally in the Battle Against SARS-CoV-2? Front. Cell Infect. Microbiol. 2020, 10, 605334. [CrossRef]

86. Shukla, R.; Ramasamy, V.; Shanmugam, R.K.; Ahuja, R.; Khanna, N. Antibody-Dependent Enhancement: A Challenge for Developing a Safe Dengue Vaccine. Front. Cell Infect. Microbiol. 2020, 10, 572681. [CrossRef]

87. Beretta, A.; Cranage, M.; Zipeto, D. Is Cross-Reactive Immunity Triggering COVID-19 Immunopathogenesis? Front. Immunol 2020, 11, 567710. [CrossRef]

88. Mudd, P.A.; Crawford, J.C.; Turner, J.S.; Souquette, A.; Reynolds, D.; Bender, D.; Bosanquet, J.P.; Anand, N.J.; Striker, D.A.; Martin, R.S.; et al. Distinct inflammatory profiles distinguish COVID-19 from influenza with limited contributions from cytokine storm. Sci. Adv. 2020, 6. [CrossRef]

89. Callow, K.A.; Parry, H.F.; Sergeant, M.; Tyrrell, D.A. The time course of the immune response to experimental coronavirus infection of man. Epidemiol. Infect. 1990, 105, 435-446. [CrossRef] [PubMed]

90. Reed, S.E. The behaviour of recent isolates of human respiratory coronavirus in vitro and in volunteers: Evidence of heterogeneity among 229E-related strains. J. Med. Virol. 1984, 13, 179-192. [CrossRef]

91. COVID-19: World's First Human Challenge Trials to Start in UK, 17 February 2021. Available online: https://www.bbc.com (accessed on 6 June 2021).

92. Kirby, T. COVID-19 human challenge studies in the UK. Lancet Respir. Med. 2020, 8, e96. [CrossRef] 
93. Kuiper, V.P.; Rosendaal, F.R.; Kamerling, I.M.C.; Visser, L.G.; Roestenberg, M. Assessment of risks associated with SARS-CoV-2 experimental human infection studies. Clin. Infect. Dis. 2020. [CrossRef]

94. Sia, S.F.; Yan, L.M.; Chin, A.W.H.; Fung, K.; Choy, K.T.; Wong, A.Y.L.; Kaewpreedee, P.; Perera, R.; Poon, L.L.M.; Nicholls, J.M.; et al. Pathogenesis and transmission of SARS-CoV-2 in golden hamsters. Nature 2020, 583, 834-838. [CrossRef] [PubMed]

95. Sealy, R.; Chaka, W.; Surman, S.; Brown, S.A.; Cresswell, P.; Hurwitz, J.L. Target peptide sequence within infectious human immunodeficiency virus type 1 does not ensure envelope-specific T-helper cell reactivation: Influences of cysteine protease and gamma interferon-induced thiol reductase activities. Clin. Vaccine Immunol. 2008, 15, 713-719. [CrossRef] [PubMed] 